\author{
Cemal ÜSTÜN, MD, Msc, ${ }^{\text {a }}$ \\ İbrahim TEĞiN, PhD, Assis.Prof., ${ }^{b}$ \\ Mehmet Faruk GEYIK, MD, Prof ${ }^{\circ}$ \\ ${ }^{a} \mathrm{Clinic}$ of Infectious Diseases and \\ Clinic Microbiology, \\ Elazığ Harput State Hospital, \\ Elazığ \\ bDepartment of Chemistry, \\ Siirt University Faculty of Science and Art, \\ Siirt \\ 'Department of Infectious Diseases and \\ Clinic Microbiology, \\ Düzce University Faculty of Medicine, \\ Düzce
}

Geliş Tarihi/Received: 13.07.2011

Kabul Tarihi/Accepted: 14.02 .2012

Yazışma Adresi/Correspondence: Cemal ÜSTÜN, MD, Msc

Elazığ Harput State Hospital,

Clinic of Infectious Diseases and

Clinic Microbiology, Elazığ,

TÜRKIYE/TURKEY

drcustun@gmail.com

\section{Alterations of Serum Copper and Zinc Levels, and Copper/Zinc Ratios Among Patients with Brucellosis}

\author{
Brusellozlu Hastalarda Serum Bakır ve \\ Çinko Düzeylerindeki ve Bakır/Çinko \\ Oranlarındaki Değişiklikler
}

\begin{abstract}
Objective: To determine the alterations of serum copper $(\mathrm{Cu})$ and zinc $(\mathrm{Zn})$ levels and $\mathrm{Cu} / \mathrm{Zn}$ ratio in patients with brucellosis. Material and Methods: A total of 170 individuals were included in the study. Of these, 45 (26.5\%) currently had acute or sub-acute brucellosis, 35 (20.6\%) were previously diagnosed with acute or sub-acute brucellosis and successfully treated, and 90 (52.9\%) were healthy volunteers. After fasting overnight for 10 hours, $5 \mathrm{ml}$ of venous blood was taken.from all subjects. Serum $\mathrm{Cu}$ and $\mathrm{Zn}$ levels were measured using a Unicam 929 Atomic Absorption Spectrophotometer. SPSS 16.0 was used for data analysis. Results: Mean serum Cu levels of 45 patients with acute or sub-acute brucellosis, 35 patients previously diagnosed with acute or sub-acute brucellosis and 90 healthy volunteers were $88.6 \pm 26,58.7 \pm 13$ and $56.7 \pm 16 \mu \mathrm{g} / \mathrm{dL}$, respectively. Mean serum Zn levels of 45 patients with acute or sub-acute brucellosis, 35 patients previously diagnosed with and treated successfully for acute or sub-acute brucellosis and 90 healthy volunteers were $38.3 \pm 12,58.5 \pm 14$, and $55.8 \pm 13 \mu \mathrm{g} / \mathrm{dL}$, respectively. Serum $\mathrm{Cu}$ levels $(\mathrm{p}<0.001)$ and $\mathrm{Cu} / \mathrm{Zn}$ ratios $(p<0.001)$ were statistically significantly higher while serum $Z n$ levels $(p<0.001)$ were lower in patients with acute or sub-acute brucellosis when compared to the individuals who previously diagnosed with acute or sub-acute brucellosis and the healthy volunteers. Conclusion: This study revealed significant alterations of serum $\mathrm{Cu}$ and $\mathrm{Zn}$ levels, and $\mathrm{Cu} / \mathrm{Zn}$ ratios in patients with acute or sub-acute brucellosis. Serum $\mathrm{Cu}, \mathrm{Zn}$, and $\mathrm{Cu} / \mathrm{Zn}$ ratios may be available biomarkers in the course of acute or sub-acute brucellosis.
\end{abstract}

Key Words: Brucellosis; copper; zinc; trace elements; serum; biological markers

ÖZET Amaç: Brusellozlu hastalarda serum bakır $(\mathrm{Cu})$ ve çinko $(\mathrm{Zn})$ düzeylerinde ve bakır/çinko oranlarındaki değişiklikleri saptamaktır. Gereç ve Yöntemler: Çalışmaya toplam 170 birey alındı. Bunların 45'i (26,5\%) akut veya sub-akut bruselloz hastası, 35'i (20,6\%) daha önce akut veya subakut bruselloz tanısı aldıktan sonra başarılı bir şekilde tedavi edilmiş hastalar ve 90'ı (52,9\%) sağlıklı gönüllüler idi. Tüm deneklerden 10 saatlik gece açlığını takiben $5 \mathrm{ml}$ venöz kan alındı. Serum $\mathrm{Cu}$ ve $\mathrm{Zn}$ düzeyleri Unicam 929 Atomik Absorbsiyon Spektrofotometresi ile ölçüldü. Verilerin incelenmesinde SPSS 16.0 kullanıldı. Bulgular: Akut veya sub-akut brusellozlu 45 hastanın, daha önce akut veya sub-akut bruselloza yakalanan 35 hastanın ve 90 sağlıklı gönüllünün ortalama serum $\mathrm{Cu}$ düzeyleri sırasıyla $88,6 \pm 26,58,7 \pm 13$ ve $56,7 \pm 16 \mu \mathrm{g} / \mathrm{dL}$ idi. Akut veya sub-akut brusellozlu 45 hastanın, daha önce akut veya sub-akut bruselloza yakalanan 35 hastanın ve 90 sağlıklı gönüllünün ortalama serum Zn düzeyleri sırasıly $38,3 \pm 12,58,5 \pm 14$, ve $55,8 \pm 13 \mu \mathrm{g} / \mathrm{dL}$ idi. Daha önce akut veya sub-akut bruselloza yakalananlarla ve sağlıklı gönüllülerle karşılaştırıldığında halen akut veya sub-akut brusellozu olan hastaların serum $\mathrm{Cu}$ düzeylerinde ve $\mathrm{Cu} / \mathrm{Zn}$ oranlarında istatistiksel olarak anlamlı yükseklik $(\mathrm{p}<0,001)$ ve serum $\mathrm{Zn}$ düzeylerinde anlamlı azalma vardı $(\mathrm{p}<0,001)$. Sonuç: $\mathrm{Bu}$ çalışma, akut veya sub-akut brusellozlu hastalarda serum $\mathrm{Cu}$ ve $\mathrm{Zn}$ düzeylerinde ve $\mathrm{Cu} / \mathrm{Zn}$ oranlarında önemli değişimleri ortaya koymuştur. Serum $\mathrm{Cu}, \mathrm{Zn}$ ve $\mathrm{Cu} / \mathrm{Zn}$ oranları akut veya sub-akut brusellozun seyrinde kullanılabilecek biyolojik belirteçler olabilir.

Anahtar Kelimeler: Bruselloz; bakır; çinko; eser elementler; serum; biyolojik belirleyiciler doi:10.5336/medsci.2011-25720

Copyright ( 2012 by Türkiye Klinikleri
Turkiye Klinikleri J Med Sci 2012;32(4):979-83 
erum trace elements, especially $\mathrm{Cu}$ and $\mathrm{Zn}$, are critically important in the human body and $\mathrm{Cu}$ and $\mathrm{Zn}$ serum levels change over the course of various diseases, including malignancy, diabetes, hypertension, gastric ulcer, psychoses, cirrhosis and infectious diseases. ${ }^{1-9}$ In the human body, these elements are an important components of many metalloenzymes. Acute phase reactants, infections and/or inflammation lead to elevated serum $\mathrm{Cu}$ levels and decreased serum $\mathrm{Zn}$ levels via cytokines, especially interleukin-1., ${ }^{4,10}$ Increased levels of serum $\mathrm{Cu}$ are attributed to inflammationrelated diseases and decreased levels of serum $\mathrm{Zn}$ suppresses the invasion of microorganisms. ${ }^{11}$ These alterations in the levels of serum $\mathrm{Cu}$ and serum $\mathrm{Zn}$ have been reported to take place at the incubation period of microorganisms. ${ }^{4,5}$ The alterations in these trace elements result from the non-specific immune defense mechanisms in the human body. ${ }^{1-}$

${ }^{7}$ An increased serum $\mathrm{Cu} / \mathrm{Zn}$ ratio has been reported to be used as an indicator for infectious diseases before development of clinical disease. ${ }^{4,5,12}$ Different studies have investigated the diagnostic value or metabolic alterations of $\mathrm{Cu}$ and $\mathrm{Zn}$, particularly in infectious diseases. ${ }^{1,2,4,5,11,13,14}$

Brucellosis is a zoonotic infectious disease that is endemic in the Southeastern region of Turkey. The morbidity of disease is rather high, while its mortality is very low. In endemic areas, it is sometimes difficult to diagnose brucellosis because of its wide-ranged clinical manifestations. In addition, there are no reliable laboratory tests to evaluate the course of the disease. Clinically, the disease is classified as acute, sub-acute, and chronic forms. This is especially true for patients with the chronic form who may have not shown any specific signs of infection. ${ }^{15-17}$ If these patients do not receive an accurate diagnosis and treatment, severe morbidity may develop. ${ }^{15,17}$ Therefore, the efforts to identify the laboratory tests that successfully diagnose and evaluate the course of the disease have become important.

The objective of this study was to determine the alterations of serum $\mathrm{Cu}$ and $\mathrm{Zn}$ levels and $\mathrm{Cu} / \mathrm{Zn}$ ratio in patients with brucellosis.

\section{MATERIAL AND METHODS}

\section{SETTING}

This case-control study was performed between January 2008 and December 2009 at Dicle University Hospital, an 1150-bed tertiary referral center, and at Elazig Teaching Hospital, a 650-bed secondary referral center. Patients with brucellosis, patients who had previously been diagnosed with with brucellosis, and healthy volunteers, above 18-years of age, were included in the study. Individuals with acute or chronic diseases, apart from brucellosis, and nutritional disorders were not included in the study. This study was approved by Local Ethic Committee of Dicle University Medical Faculty. The study protocol conforms to the ethical guidelines of the 2008 declaration of Helsinki.

\section{DEFINITION OF CASES AND CONTROLS}

The diagnosis of patients with acute or sub-acute brucellosis, who have less than 12-month-history of the disease, was made based on clinical findings, including weakness, fatigue, undulant fever, night perspiration, and muscle-joint pain as well as laboratory findings including elevated erythrocyte sedimentation rate (ESR) and serum C-reactive protein (CRP). Furthermore, a rose bengal test and a Wright agglutination test were obtained. Patients with no prominent clinical and laboratory findings as mentioned above, but with a positive rose bengal test, a Wright test with a titer greater than $1 / 160$ and positive for more than 12-monthhistory of the disease were diagnosed with chronic brucellosis. ${ }^{15-17}$ All patients received antibiotics after serum samples were taken to test for brucellosis at least for six weeks.

This study included two control groups. The first control group (C-I) included 35 subjects who were previously diagnosed with acute or sub-acute brucellosis between January 2005 and December 2007. These patients had been successfully treated at least for six weeks. None of the 35 cases showed any clinical or significant laboratory signs of brucellosis. The second control group (C-II) included 90 healthy volunteers. 


\section{MEASUREMENT OF SERUM CU AND SERUM ZN LEVELS}

After the required information and approval were obtained and 170 subjects had fasted overnight for 10 hours, a total of $5 \mathrm{~mL}$ of venous blood was taken from the median cubital vein. The blood samples were immediately decomposed by centrifuging the samples at 5200 turns for 5 minutes at room temperature. Serum samples were stored in deep freeze at $-80^{\circ} \mathrm{C}$. When working with the samples, all serum samples were dissolved and diluted with deionized water at the room temperature. $\mathrm{Cu}$ and Zn levels were measured in all serum samples using a Unicam 929 Atomic Absorption Spectrophotometer.

\section{STATISTICAL ANALYSIS}

All the data collected from the study cases and both control groups were analyzed using SPSS 17.0 statistical software (Windows Version). KolmogorovSmirnov test was used to test the distribution of data in each group. One-way ANOVA test was used to compare the data between patients with brucellosis and both control groups. $\mathrm{p}$ values smaller than 0.05, were accepted as significant. Bonferroni test was used for homogeneous data and the Tamhane test for heterogeneous data. Statistical power for One-way ANOVA test has been calculated as $80-89 \%$.

\section{RESULTS}

The demographic characteristics and some biochemical parameters of patients with acute or subacute brucellosis and both controls groups are shown in Table 1 . No statistically significant differences were found between the patients with acute or sub-acute brucellosis and both controls groups in terms of gender $(\mathrm{p}=1)$ and age $(\mathrm{p}=0.8)$. The rose bengal test was positive in patients with acute or sub-acute brucellosis, and their Wright agglutination test showed a titer greater than 1/160. All laboratory parameters of the C-I and C-II groups were in normal ranges. In five individuals from C-I group, rose bengal test was positive and Wright test had a titer smaller than $1 / 80$, which were considered as normal. Serum $\mathrm{Cu}$ and serum $\mathrm{Zn}$ levels, $\mathrm{Cu} / \mathrm{Zn}$ ratios, and the statistical results of patients with acute or sub-acute brucellosis, and individuals in the $\mathrm{C}-\mathrm{I}$ and $\mathrm{C}-\mathrm{II}$ groups are shown in Table 2. Serum Cu levels were statistically significantly higher and serum Zn levels were statistically significantly lower in patients with acute or subacute brucellosis when compared with both control groups. Additionally, $\mathrm{Cu} / \mathrm{Zn}$ ratios were statistically significantly higher in patients with acute or sub-acute brucellosis when compared to $\mathrm{Cu} / \mathrm{Zn}$ ratios of both control groups. No statistically significant differences were found between $\mathrm{C}$-I and $\mathrm{C}$-II groups in terms of serum Cu levels $(\mathrm{p}=0.8)$, serum $\mathrm{Zn}$ levels $(\mathrm{p}=0.8)$, and $\mathrm{Cu} / \mathrm{Zn}$ ratios $(\mathrm{p}=1)$. $\mathrm{Cu} / \mathrm{Zn}$ ratios of patients with acute or sub-acute brucellosis and $\mathrm{Cu} / \mathrm{Zn}$ ratios of individuals in C-I and C-II groups are shown in the Figure 1. As the Figure shows, serum $\mathrm{Cu} / \mathrm{Zn}$ ratios were as high as 2.0 in patients with acute or sub-acute brucellosis. $\mathrm{Cu} / \mathrm{Zn}$ ratios between the patients with acute or sub-acute brucellosis and individuals in both control groups did not intersect (Figure 1). Conversely, $\mathrm{Cu} / \mathrm{Zn}$ ratios of individuals in $\mathrm{C}-\mathrm{I}$ and $\mathrm{C}-\mathrm{II}$ groups were found to be almost equivalent (Table 2, Figure 1). Patients with chronic brucellosis were not included in this study since such patients could not be found.

\section{DISCUSSION}

There is a growing interest in investigating the alterations of serum trace elements in the course of

TABLE 1: Demographic characteristics and some biochemical parameters of patients with brucellosis and both controls.

\begin{tabular}{|c|c|c|c|c|c|}
\hline Study cases & Mean age (Year $\pm S d)$ & Gender (Male \%) & BLC (Mean $\left./ \mathrm{mm}^{3}\right)$ & $\mathrm{CRP}(\mathrm{mg} / \mathrm{L} \pm \mathrm{Sd})$ & $\mathrm{ESR}(\mathrm{mm} / \mathrm{h} \pm \mathrm{Sd})$ \\
\hline Brucellosis $(n=45)$ & $39.5 \pm 13$ & $49 \%$ & 9.500 & $72 \pm 25$ & $56 \pm 17$ \\
\hline C-I $(n=35)$ & $37.9 \pm 11$ & $51 \%$ & 7.800 & $\leq 5$ & $\leq 10$ \\
\hline C-II $(n=90)$ & $39.1 \pm 9$ & $50 \%$ & 8.200 & $\leq 5$ & $\leq 10$ \\
\hline
\end{tabular}

Sd: Standard deviation; BLC: Blood leukocyte count; CRP: C-reactive protein (Normal range: 0-6 mg/L); ESR: Erythrocyte sedimentation rate (Normal range: 0-16 mm/h). 
TABLE 2: The mean values of serum $\mathrm{Cu}$, serum $\mathrm{Zn}$, and the $\mathrm{Cu} / \mathrm{Zn}$ ratios in patients with brucellosis and in both control groups, along with statistical results.

\begin{tabular}{|lcccc|} 
& Brucellosis & C-I & C-II & \\
Trace elements & $\mathrm{n}=45$ & $\mathrm{n}=35$ & $\mathrm{n}=90$ & $\mathrm{p}$ \\
$\mathrm{Cu}(\mu \mathrm{g} / \mathrm{dL} \pm \mathrm{Sd})$ & $88.6 \pm 26$ & $58.7 \pm 13$ & $56.7 \pm 16$ & $<0.001$ \\
$\mathrm{Zn}(\mu \mathrm{g} / \mathrm{dL} \pm \mathrm{Sd})$ & $38.3 \pm 12$ & $58.5 \pm 14$ & $55.8 \pm 13$ & $<0.001$ \\
$\mathrm{Cu} / \mathrm{Zn}$ & $2.3 \pm 0.13$ & $1.0 \pm 0.09$ & $1.0 \pm 0.06$ & $<0.001$ \\
\hline
\end{tabular}

Sd: Standard deviation

different diseases. Many studies have been conducted to examine the relationship between serum $\mathrm{Cu}$ and serum $\mathrm{Zn}$ levels and various diseases, especially infectious diseases. . $2,4,5,7,8,10,11,13,14,18$ This is the first study that compares the serum $\mathrm{Cu} / \mathrm{Zn}$ ratios in patients with brucellosis and individuals in two different control groups. In general, there are two types of abnormalities in the levels of trace elements. The first abnormality is an inadequate intake or an unbalanced intake of $\mathrm{Cu}$ and $\mathrm{Zn}$ as a result of diet, and the second abnormality is the presence of a disease that can affect the patient's serum levels. Individuals with nutritional disorders and diseases apart from brucellosis were not included in this study in order to reveal more reliable results.

The present study has shown statistically significantly higher serum $\mathrm{Cu}$ levels and $\mathrm{Cu} / \mathrm{Zn}$ ratios, and lower serum $\mathrm{Zn}$ levels in patients with acute or sub-acute brucellosis. Cesur et al. and
Kalkan et al. have reported results similar to those found in our study. ${ }^{2,11}$ However, these studies have not been conducted using two control groups and they have not examined serum $\mathrm{Cu} / \mathrm{Zn}$ ratios in patients with brucellosis and individuals in control groups. Besides, patients were not categorized as acute or sub-acute and chronic brucellosis in these studies. We performed the present study with two different control groups in order to obtain more reliable results. Increased serum $\mathrm{Cu}$ levels and decreased serum $\mathrm{Zn}$ levels in patients with brucellosis are the result of an immune defense mechanism in the human body, which has been well-documented in literature. ${ }^{1,2,10,11}$ Herein, we aimed to clarify whether serum $\mathrm{Cu}$ levels, serum $\mathrm{Zn}$ levels, and $\mathrm{Cu} / \mathrm{Zn}$ ratio were available biomarkers to aid diagnosis of brucellosis or to assess the course of the disease. Sullivan et al. have reported that serum $\mathrm{Cu}$ levels and serum $\mathrm{Zn}$ levels are significantly altered in many diseases, including infections, malignancy, diabetes, arthritis, ulcer, psychoses, cirrhosis, pancreatitis, hypertension, cardiovascular diseases, and chronic obstructive pulmonary disease. ${ }^{1}$ Additionally, Sfar et al. and Mazetti et al. have reported that aging may change serum $\mathrm{Cu}$ levels and serum Zn levels. ${ }^{7,18}$ Although statistically significant alterations in serum $\mathrm{Cu}$ levels and serum $\mathrm{Zn}$ levels exist in a wide range of diseases, these alterations are not specific to any diseases, including infectious ones. Yet, we observed in this study that $\mathrm{Cu} / \mathrm{Zn}$ ratios did not intersect between

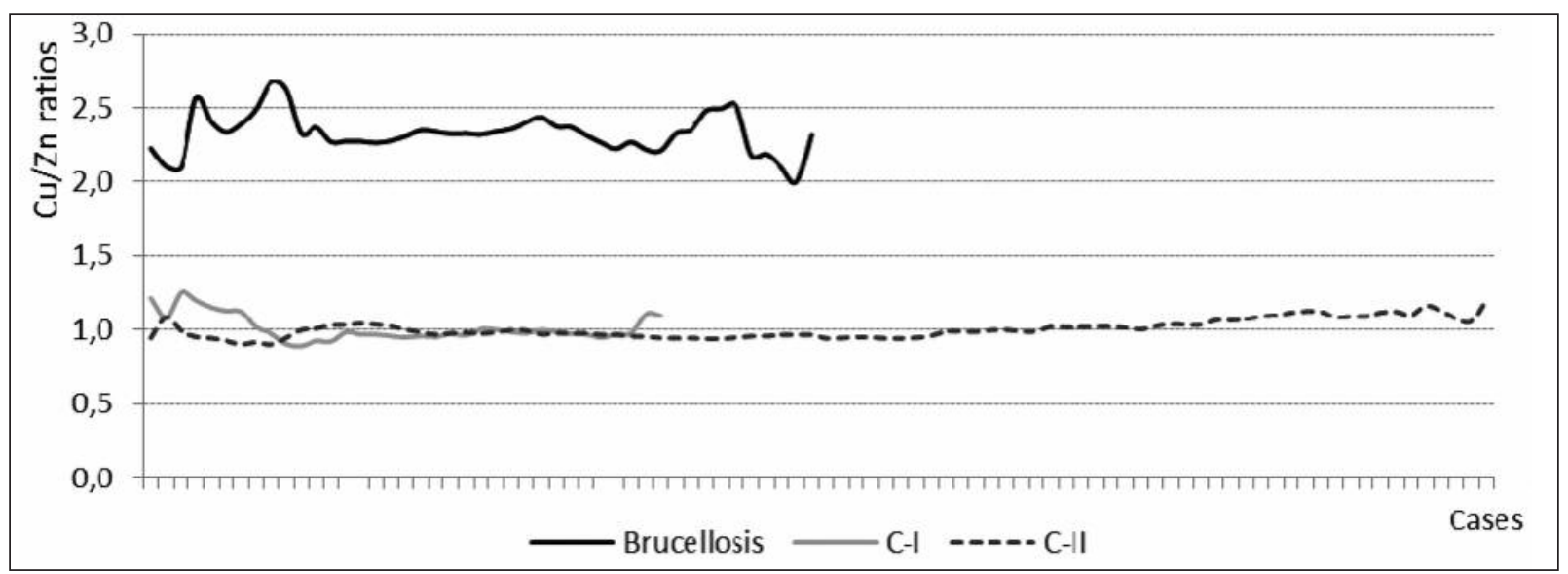

FIGURE 1: Serum Cu/Zn ratios in patients with brucellosis, and in individuals in the C-I and C-II groups. 
patients with acute or sub-acute brucellosis and individuals in both control groups. Furthermore, increased $\mathrm{Cu} / \mathrm{Zn}$ ratios, found greater than 2.0, were considered to be important among patients with acute or sub-acute brucellosis when compared to both control groups. Also, no statistically significant differences were found in serum $\mathrm{Cu}$ levels, serum $\mathrm{Zn}$ levels, and $\mathrm{Cu} / \mathrm{Zn}$ ratios between two control groups. This condition may indicate that serum $\mathrm{Cu} / \mathrm{Zn}$ ratio, especially greater than 2.0 , may be valuable in both aiding diagnosis of acute or sub-acute brucellosis and evaluating the course of the disease. Also, serum $\mathrm{Cu} / \mathrm{Zn}$ ratio may be useful in response to therapy of patients with acute or sub-acute brucellosis. However, serum $\mathrm{Cu} / \mathrm{Zn}$ ratio was not determined at the end of antibacterial treatment of patients with brucellosis due to some limitations in the present study. This may be investigated by the controlled further studies.
There are some limitations of this study. First, the differences between patients with acute brucellosis and sub-acute brucellosis were not done. Second, patients with chronic brucellosis were not included in this study as we could not find patients with chronic brucellosis. All cases of this study were patients who had either acute or sub-acute brucellosis. These limitations may be available to be considered in future studies.

In conclusion, the present study has revealed the significant differences in serum $\mathrm{Cu}$ and $\mathrm{Zn} \mathrm{lev-}$ els in patients with acute and sub-acute brucellosis. Serum $\mathrm{Cu}, \mathrm{Zn}$, and $\mathrm{Cu} / \mathrm{Zn}$ ratio may be available biomarkers in both aiding diagnosis and evaluating the course of acute or sub-acute brucellosis.

\section{Acknowledgement}

The authors declare no conflict of interest or any financial support relevant to this study.

\section{REFERENCES}

1. Sullivan JF, Blotcky AJ, Jetton MM, Hahn HK, Burch RE. Serum levels of selenium, calcium, copper magnesium, manganese and zinc in various human diseases. J Nutr 1979;109(8): 1432-7.

2. Kalkan A, Bingöl NK, Bulut V, Erel Ö, Kılıç SS. [Serum, copper, zinc and selenium concentrations in brucellosis]. Turkish Journal of Infection 2000;14(4):205-8.

3. Brewer GJ. Anticopper therapy against cancer and diseases of inflammation and fibrosis. Drug Discov Today 2005;10(16):1103-9.

4. Edvinsson M, Frisk P, Molin Y, Hjelm E, llbäck NG. Trace element balance is changed in infected organs during acute Chlamydophila pneumoniae infection in mice. Biometals 2008;21(2):229-37.

5. Pekarek RS, Kluge RM, DuPont HL, Wannemacher RW Jr, Hornick RB, Bostian KA, et al. Serum zinc, iron, and copper concentrations during typhoid fever in man: effect of chloramphenicol therapy. Clin Chem 1975;21(4):52832.

6. Kouremenou-Dona E, Dona A, Papoutsis J, Spiliopoulou C. Copper and zinc concentrations in serum of healthy Greek adults. Sci Total Environ 2006;359(1-3):76-81.
7. Sfar S, Jawed A, Braham H, Amor S, Laporte F, Kerkeni A. Zinc, copper and antioxidant enzyme activities in healthy elderly Tunisian subjects. Exp Gerontol 2009;44(12):812-7.

8. Türk M, Yazar S, Kıııç E, Saraymen R, Türker M. [Assessment of serum levels of copper, magnesium, and zinc in patients infected with Trichinella britovi]. Turkiye Klinikleri J Med Sci 2009;29(3):589-93.

9. Matousek de Abel de la Cruz AJ, Burguera JL, Burguera M, Añez N. Changes in the total content of iron, copper, and zinc in serum, heart, liver, spleen, and skeletal muscle tissues of rats infected with Trypanosoma cruzi. Biol Trace Elem Res 1993;37(1):51-70.

10. Kalkan A, Bulut V, Avci S, Celik I, Bingol NK. Trace elements in viral hepatitis. J Trace Elem Med Biol 2002;16(4):227-30.

11. Cesur S, Kocaturk PA, Kavas GO, Aksaray S, Tezeren D, Ciftci U. Serum copper and zinc concentrations in patients with brucellosis. J Infect 2005;50(1):31-3.

12. Saner G, Baysal SU, Ünüvar E, Özden T. Serum zinc, copper levels, and copper/zinc ratios in infants with sepsis syndrome. J Trace Elem Exp Med 2000;13(3):265-70.

13. Agay D, Anderson RA, Sandre C, Bryden NA, Alonso A, Roussel AM, et al. Alterations of an- tioxidant trace elements $(\mathrm{Zn}, \mathrm{Se}, \mathrm{Cu})$ and related metallo-enzymes in plasma and tissues following burn injury in rats. Burns 2005;31(3): 366-71.

14. Cesur S, Cebeci SA, Kavas GO, Aksaray S, Tezeren D. Serum copper and zinc concentrations in patients with chronic hepatitis B. J Infect 2005;51(1):38-40.

15. Gotuzzo E, Carillo C. Brucella. In: Gorbach SL, Bartlett JG, Blacklow NR, eds. Infectious Diseases. $1^{\text {st }}$ ed. Philadelphia: Lippincott Williams \& Wilkins; 2004. p.1717-24.

16. Manuselis G. Haemophilus and other fastidious Gram-negative bacilli. In: Mahon CR, Lehman DC, Manuselis G, eds. Textbook of Diagnostic Microbiology. $4^{\text {th }}$ ed. Missouri: Saunders Elsevier; 2011. p.395-414.

17. Young EJ. Brucella species. In: Mandell GL, Bennett JE, Dolin R, eds. Principles and Practice of Infectious Diseases. $6^{\text {th }}$ ed. Philadelphia: Churchill Livingstone Elsevier; 2010. p.2921-5.

18. Mezzetti A, Pierdomenico SD, Costantini F, Romano F, De Cesare D, Cuccurullo F, et al. Copper/zinc ratio and systemic oxidant load: effect of aging and aging-related degenerative diseases. Free Radic Biol Med 1998;25(6): 676-81. 
Copyright of Turkiye Klinikleri Journal of Medical Sciences is the property of Ortadogh Reklam Tanitim ve Yayincilik Turizm Egitim Insaat Sanayi ve Ticaret A.S. and its content may not be copied or emailed to multiple sites or posted to a listserv without the copyright holder's express written permission. However, users may print, download, or email articles for individual use. 